Contents list available at Multidisciplinary Journal website Multidisciplinary Journal

Journal homepage: https://jurnal.unej.ac.id/index.php/multijournal

\title{
Lumbung Pangan Sebagai Upaya Ketangguhan Pangan Masa Pandemi Covid-19 Desa Kabuaran Bondowoso
}

\author{
Food Storage an Effort Food Resilience During the Pandemic Covid-19 in Kabuaran Bondowoso \\ Merissa Pramudita ${ }^{1}$, Devit Dewi Anggraini ${ }^{2}$, Nurul Hidayat ${ }^{3}$, Erisa Yuniardiningsih ${ }^{4}$, Meri Dwi Apriliyanti ${ }^{5}$, \\ Pandan Wangi ${ }^{6}$, Isa Ma'rufi ${ }^{7}$ \\ ${ }^{1-7}$ Program Studi Magister Ilmu Kesehatan Masyarakat, Universitas Jember \\ Email: merissapramudita@gmail.com
}

\begin{abstract}
ABSTRAK. Pangan menjadi pusat perhatian dan paling pokok dalam upaya ketangguhan pangan masyarakat tertama pada masa pandemi covid-19 ini. Dalam menjamin ketesediaan bahan pangan, desa adalah pusat pangan yang memiliki peran serta dalam menjamin ketersediaan pangan baik dalam tingkat desa, kabupaten, provisi, bahkan nasional. Pasal 74 UU 6/2014 tentang desa memberikan kewenangan kepada desa untuk memprioritaskan belanja kebutuhan pembangunan, diantaranya kebutuhan primer yakni pangan. Tujuan penelitian ini adalah untuk mengetahui peran lumbung pangan sebagai upaya ketangguhan pangan di masa pandemi covid-19 di Desa Kabuaran Kecamatan Grujugan Kabupaten Bondowoso. Metode yang digunakan dalam studi ini yaitu metode kualitatif dengan desain studi kasus. Lokasi kegiatan berada di Desa Kabuatan Kecamatan Grujugan Kabupaten Bondowoso dengan subjek penelitian diantaranya meliputi Kepala Desa Kabuaran sebagai informan kunci; Sekertaris Desa Kabuaran, Bendahara Desa dan Ketua Satgas Covid-19 sebagai informan utama; kader lumbung pangan, serta pihak yang berkaitan dengan pengelolaan lumbung pangan Desa Kabuaran sebagai informan pendukung. Teknik pengambilan sampel melalui sampling purposive. Sumber data diperoleh dari data primer (checklist dan wawancara) dan sekunder (dokumen atau file desa, arsip desa). Hasil penelitian ini menunjukkan lumbung pangan yang terdapat pada kampung tangguh semeru Desa Kabuaran dengan kondisi yang baik terlihat dari ketersediaan stok pangan, administrasi, peruntukan lumbung pangan, alur penerimaan dan pendistribusian bahan pangan yang tertata, juga terdapat inovasi untuk ketangguhan pangan yaitu JSG yaitu Jahe, Serai, Gula. Dengan cara memanfaatkan tanaman toga yang di tanam di halaman rumah masing-masing warga. Jadi selain meningkatkan kesehatan, masyarakat Desa Kabuaran juga dapat meningkatkan ekonomi dengan menjual ramuan JSG. Kesimpulan pada penelitian ini lumbung pangan memiliki peran penting dalam setiap kehidupan manusia terutama pada kondisi pandemi covid-19 yang sedang terjadi saat ini. Lumbung pangan ini menjadikan kampung yang tangguh sehingga dapat berdaya di masa pandemi sehingga dapat mencapai kampung tangguh yang mampu mandiri.
\end{abstract}

Kata Kunci: COVID-19, ketangguhan pangan, lumbung pangan

\begin{abstract}
Food becomes the main concern in food reliance effort for the society particularly during the COVID19 Pandemic. To guarantee the food supply, village plays the essential role to ensure the food supply for village, regency, province and the nation. The Act 74 regulation no 6/2014 on village provides an authority for villages to prioritize its budget for development, including primary necessity on food. This research aims at revealing the role of food barn as the attempt to achieve food resilience during the pandemic in Kabuaran Village Grujugan District Bondowoso Regency. The method applied is qualitative with case study. Research area cover Kabuatan Village Grujugan District Bondowoso Regency with the subjects including head village of Kabuaran as the key informant, the village secretary, the treasurers and the head of Covid-19 Task Force as the main informant, Food Barn Cadre as well as those related to food barn management in Kabuaran Village as the supporting informants. Purposive Sampling is used and data were collected primarily by check list and interview dan secondary data includes documents or file from village's archives. The results shows that the food barn located in Semeru Resilient Village Kabuaran is in good condition as evidenced in the food supply, administration, food supply distribution, recipient line up and well-arranged food distribution and the availability of innovation such as Ginger, lemongrass and sugar. Herbs and traditional medicine plants are well taken care of and used by the villagers. To conclude, the food barn constructs resilient in villagers life particularly during the pandemic covid19. The food barn enables village to be resilient and independent.
\end{abstract}

Keywords: COVID-19, food resilience, food barn 


\section{Pendahuluan}

Pandemi covid-19 yang menjadi ancaman global saat ini membawa dampak pada berbagai segmen termasuk jaminan akan ketersediaan pangan. Food and Agriculture Organization (FAO) of the United Nations (2020) menyatakan pandemi covid-19 dapat mempengaruhi keamanan pangan melalui gangguan ketersediaan tenaga kerja dan rantai pasokan makanan. FAO memprediksi krisis pangan dan kekeringan akan melanda negara negara, termasuk Indonesia [3].

Berdasarkan data BPS, tahun 2020, Indonesi memproduksi beras pada tahun 2019 mengalami penurunan sebanyak 2,63 juta ton / 7,75\% jika dibandingkan dengan tahun 2018. Kondisi ini diharapkan tidak terjadi di tengah pandemi covid19, karena kebijakan impor beras untuk mencukupi kebutuhan pangan nasional akan sulit dilakukan. Negara produsen beras seperti Vietnam dan Thailand membatasi ekspor untuk memastikan dan mengamankan pasokan dalam negerinya tercukupi [1]. Selain itu, berdasarkan data FAO, India, Vietnam, dan Thailand telah menaikkan biaya ekspor beras [12].

Di sisi lain tren konsumsi masyarakat di Indonesia cenderung meningkat. Selama periode JanuariApril 2020 terjadi kenaikan Indeks Konsumsi Rumah Tangga (IKRT). April 2020 meningkat sebesar 0,11 persen dibanding bulan sebelumnya dimana kelompok pengeluaran makanan dan minuman menyumbang 0,08 persen serta penyediaan makanan dan minuman/restoran 0,12 persen [2]. Pada periode Januari sampai Maret 2020, menunjukkan bahwa terjadinya peningkatan rata-rata harga beras yaitu $0,8 \%$ berdasarkan data dari pusat informasi harga pangan strategis nasional. Kondisi ini membutuhkan penyesuaian kebijakan terkait pangan agar ketahanan pangan di Indonesia tetap terjamin.

Dalam membangun ketahanan pangan, tiga pilar yang perlu diperhatikan adalah ketersediaan (availability), keterjangkauan fisik maupun ekonomi (accessibility), dan stabilitas pasokan dan harga (stability). Menurut Peraturan Pemerintah Nomor 83 Tahun 2017, ketersediaan pangan meliputi peningkatan produksi pangan dalam negeri dan penguatan cadangan pangan nasional.

Kerawanan pangan pada masyarakat dapat diatasi dengan lumbung pangan yang merupakan lembaga cadangan pangan pada daerah desa. Walau lumbung pangan ini memiliki peran untuk mengatasi kerawanan pangan di dalam masyarakat daerah rawan pangan kronis, namun pada lembaga cadangan makanan tersebut belum mampu dalam mengatasi kerawanan pangan akibat dari kondisi yang tidak terduga seperti pandemi covid-19 yang terjadi saat ini. Keberadaan cadangan pangan yang ada pada masyarakat sekitar tidak terlepas dari adanya lembaga pengelolaan cadangan pangan. Lumbung pangan secara tradisional tumbuh dan memiliki peranan besar dalam menjaga keseimbangan ketahanan pangan pada masyarakat. [11].

Desa adalah sentra produksi pangan. Dari total 74.953 desa di Indonesia, $82.77 \%$ desa berbasis pertanian (Kemendesa, 2018). Menjaga desa tetap produktif berarti menjaga ketahanan pangan nasional. Hal ini sejalan dengan amanat UndangUndang Nomor 41 Tahun 2009 tentang Perlindungan Lahan Pertanian Pangan Berkelanjutan. Upaya yang berkelanjutan menjadi keharusan untuk mengantisipasi krisis pangan di tengah pandemi [16].

Pangan seharusnya memang menjadi pusat perhatian sebagai urusan paling pokok dari ketahanan masyarakat di tengah gempuran covid19. Nyatanya, isu ketahanan pangan baru marak dibicarakan setelah tiga bulan Indonesia berkutat dengan kesehatan, jaring pengaman sosial, dan ketenagakerjaan. Restriksi sosial yang telah diatur Pemerintah Pusat dan juga kebijakan tentang karantina yang diatur oleh beberapa Pemerintah Daerah, sudah mengubah pola dari rantai pasok pangan. Di sisi produksi, protokol kesehatan yang perlu diterapkan dalam bertani, terutama di daerah yang sudah memiliki kasus positif covid-19, mengganggu pasokan input [10].

Ketangguhan pangan adalah bagi suatu Negara serta perorangan yang kondisinya sudah terpenuhi dari segi pangan yang dapat dilihat dari terpenuhinya pangan, baik dari jumlah serta mutunya, beraneka ragam, keamanannya, gizi, merata, tidak bertentangan dari agama dan budaya masyarakat, serta terjangkau sehingga dapat hidup dengan sehat, produktif serta aktif secara berkepanjangan (Peraturan Pemerintah Republik Indonesia Nomor 17 Tahun 2015 tentang Ketahanan Pangan dan Gizi)[9]. Hal ini penting diketahui dan diupayakan karena keluarga merupakan awal dari kehidupan bagi semua anggota keluarga, terutama dalam pemenuhan kebutuhan pokok, seperti bahan makanan bergizi, pendidikan, dan kesehatan. Ketahanan pangan menjadi masalah yang sangat mendasar bagi pemenuhan kebutuhan pokok masyarakat. Selain itu juga menjadi isu penting pada situasi bencana, termasuk bencana pandemi covid-19. Pandemi covid-19 ini menerpa Indonesia sejak Pemerintah mengumumkan pada tanggal 2 Maret 2020 untuk pertama kalinya terdeteksi dua kasus pasien positif covid-19. Dampak dari kemunculan pandemi ini 
adalah pembatasan aktivitas masyarakat yang berskala besar untuk mengurangi penyebaran virus ini. Covid-19 merupakan penyakit berisiko dan dapat menyebabkan kedaruratan sehingga pemerintah menerapkan kebijakan untuk mengurangi aktivitas masyarakat. Kebijakan tersebut seperti social distancing, phycical distancing, mencuci tangan dengan sabun, diikuti juga dengan kebijakan untuk work from home dan school from home. Pandemi ini memaksa semua elemen masyarakat melakukan semua aktivitas dari rumah. Hal ini menimbulkan kekhawatiran banyak pihak mengenai kelangkaan bahan pangan akibat pembatasan aktivitas masyarakat [13].

Desa menjadi pusat produksi pangan yang mempunyai fungsi strategis, untuk memastikan adanya pangan, di tingkat desa sampai nasional. Pasal 74 UU 6/2014 berisi tentang kewenangan yang diberikan kepada desa untuk memprioritaskan belanja kebutuhan dalam pembangunan, salah satunya tentang kebutuhan primer yakni pangan. Hal ini diperkuat dengan Pasal 8 ayat (1c) Permen desa Nomor 6 Tahun 2020 menyatakan Dana Desa bisa dimanfaatkan dalam pengadaan, membangun, mengembangankan, serta pemeliharaan usaha budidaya pertanian dan perikanan sebagai ketahanan pangan. Untuk mengurangi beban masyarakat, terutama masyarakat yang rentan dan terdampak covid-19, pemerintah menerbitkan Peraturan Pengganti Undang-Undang (Perpu) Nomor 1 Tahun 2020 dan memberikan stimulus sebesar Rp 110 triliun untuk Jaring Pengaman Sosial (JPS). Diantara tujuh komponen JPS, alokasi untuk BLT Dana Desa sebesar Rp 31.789 triliun [10].

Berangkat dari pandemi COVID-19 ini yang belum diketahui waktu berakhirnya, peranan lumbung pangan desa sangat bermanfaat untuk masyarakat desa. Dimana Desa Kaburan ini beberapa waktu yang lalu memiliki tiga orang warga reaktif melalui rapid test dalam rumah isolasi Desa Kabuaran Kecamatan Grujugan Kabupaten Bondowoso. Kajian ini bertujuan untuk memotret berbagai kondisi ketersediaan pangan di desa dan kebijakan yang diambil desa dalam menjaga ketahanan pangan.

\section{Bahan dan Metode}

Pada kegiatan ini tentang lumbung pangan pada masa pandemi covid-19 yang berperan sebagai ketahanan pangan. Penelitian ini menggunakan metode penelitian kualitatif dan desain penelitian studi kasus. Lokasi kegiatan berada di Desa Kabuatan Kecamatan Grujugan Kabupaten
Bondowoso dengan subjek penelitian diantaranya meliputi Kepala Desa Kabuaran sebagai informan kunci; Sekertaris Desa Kabuaran, Bendahara Desa dan Ketua Satgas Covid-19 sebagai informan utama; Kader Lumbung pangan, dan pihak yang berhubungan dengan pengelola lumbung pangan di Desa Kabuaran sebagai informan pendukung. Teknik pengambilan sampel menggunakan sampling purposive (pengambilan sampel dengan menentukan kriteria tertentu) sehingga mendapatkan orang yang ahli dan terpercaya.

Penelitian ini menggunakan jenis data berupa teks, simbol, kata tertulis yang didapatkan dari berbagai sumber informasi. Sumber informasi penelitian ini diperoleh dari data primer maupun sekunder. Checklist dan wawancara digunakan untuk mendapatkan data primer yang dilakukan secara langsung di lapangan terhadap subjek dan objek yang terkait. Data sekunder diperoleh dari sumber yang sudah ada yaitu dari dokumen/file desa, arsip desa, kajian pustaka dan laporan penelitian sebelumnya.

\section{Hasil dan Pembahasan}

Covid-19 selain dapat membatasi ruang gerak masyarakat, dapat juga memengaruhi kondisi ekonomi sehingga berdampak dalam kemampuan masyarakat untuk mendapatkan pangan. Pemerintah berusaha dengan keras agar masyarakat tetap memperoleh bahan pangan. Berbagai intervensi kebijakan pun dilakukan untuk menjaga kondisi ketahanan pangan agar tetap stabil.

Lumbung pangan di Desa Kabuaran Kecamatan Grujugan Kabupaten Bondowoso merupakan salah satu upaya pemerintah dalam ketahanan pangan desa yang masuk dalam tujuh kriteria kampung tangguh. Kegiatan ini dilakukan dengan harapan dapat menstabilkan asupan nutrisi masyarakat menengah kebawah sehingga masyarakat memiliki imun yang kuat dan mengurangi risiko penularan covid-19.

Hal utama yang harus diperhatikan pemerintah adalah dengan menjaga ketahanan pangan, terutama seperti saat ini yaitu di masa pandemi Covid-19. Memastikan pasokan makanan bagi masyarakat harus diperhatikan di samping kebutuhan lainnya. Lokasi Lumbung Pangan terletak di belakang posko kampong tangguh tepatnya di Dusun Krajan Selatan, Kabuaran, Grujugan, Bondowoso. Kondisi lumbung pangan baik yaitu berada di rumah warga yang sukarela menjadikan ruang kosong di rumahnya sebagai tempat lumbung pangan. Ketersediaan stok pangan selama pandemi Covid-19 ini selalu ada dan 
tersedia dengan baik, banyak sukarelawan dari warga mampu yang turun menyumbangkan bahan pangan di lumbung pangan tersebut.

Pada masa pandemi ini, indikator kualitatif dari para ketua RW untuk orang terdampak sangat dibutuhkan. Untuk mengetahui pasti warga yang terdampak paling buruk pada lingkungan, para ketua RW ini sangat berperan penting, sehingga saat pemberian kuota pada suatu RW, kemudian para ketua RT dan RW menentukan warga untuk diberikan bantuan pangan agar pemberian bantuan ini tepat sasaran. Transparansi distribusi melalui pembentukan Lumbung Pangan Komunitas (LPK) telah dilakukan untuk menghindari ketidakjujuran para ketua RW.

Alur pendistribusian dijelaskan secara rinci setelah mengetahui nama dan jumlah kuota, seperti digambarkan pada bagan di bawah ini :

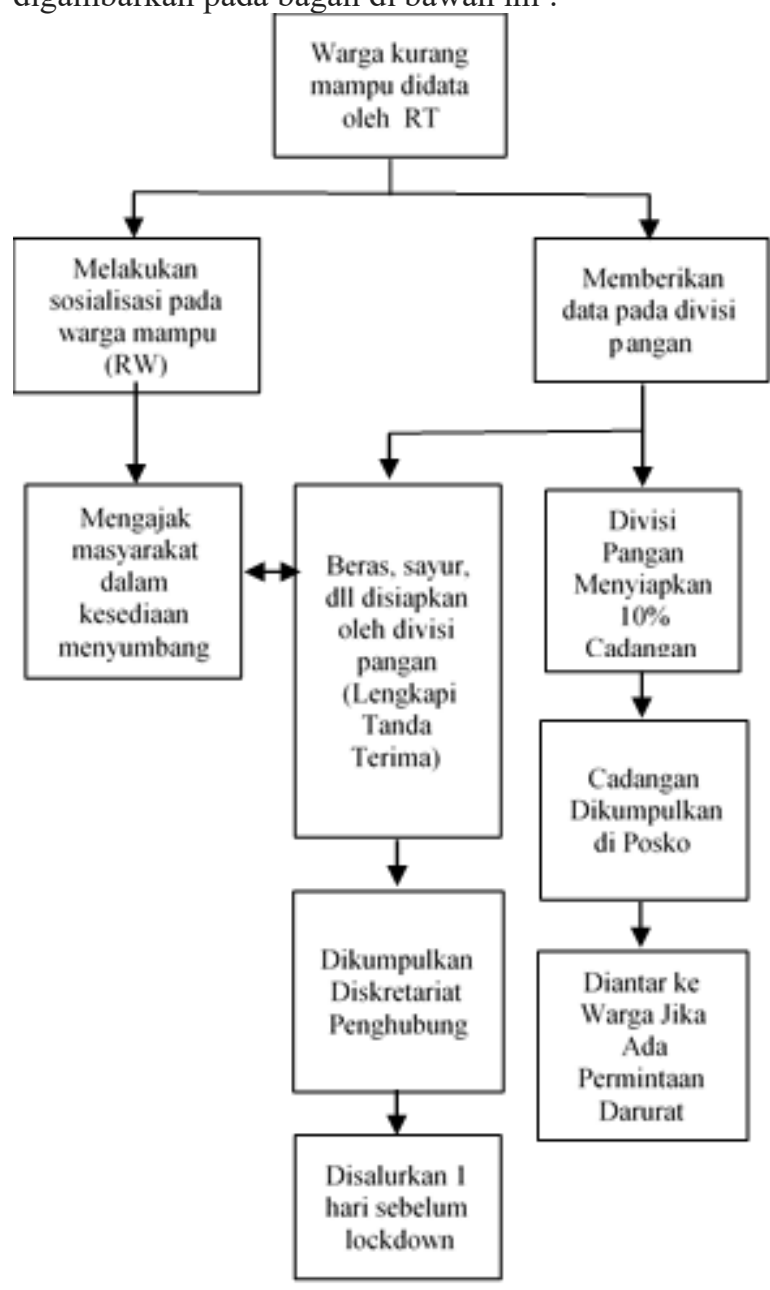

Panitia kampung tangguh membuat lumbung pangan kampung dan sumbangan warga mampu untuk menambah ketahanan pangan warga agar tidak selalu tergantung pada pemerintah. Bantuan pangan ini terutama bagi warga yang tidak mampu untuk menghindari masalah sosial dan meminimalisir penyebaran penyakit selama mengikuti aturan pemerintah untuk dirumah saja. Rekomendasi warga mampu untuk membangun lumbung pangan pada tiap-tiap RT dengan mengisi form yang berisikan jenis bantuan, jumlah serta tanda tangan penyumbang.

Peraturan kampung tangguh tentang bantuan pangan saat pandemi covid-19 yaitu :

1. Selama pandemi covid-19, penyaluran bantuan pangan dari berbagai pihak cukup banyak dan seringkali tumpang tindih, sehingga terjadi ketidak-adilan dalam distribusi bantuan. Masalah sosial dapat muncul ketika hal tersebut terjadi dalam jangka panjang.

2. Lumbung pangan kampung ini digunakan sebagai instrumen untuk merapikan catatan bantuan pangan oleh relawan, pemerintah, dan donatur lainnya termasuk zakat pribadi atau dari basis.

3. Bantuan pangan dari relawan sebaiknya $70-60 \%$ diberikan langsung ke warga dan 40\%$30 \%$ disimpan di lumbung pangan kampung/RW untuk cadangan saat krisis, atau jika bantuan tidak jelas sasarannya (nama dan alamat rumahnya).

4. Semua bantuan dicatat dalam buku penerimaan bantuan baik dari individu, instansi, donatur, atau pihak-pihak lain yang berderma (warna coklat).

5. Pencatatan dilakukan pada papan kendali bantuan jika terdapat bantuan yang sudah ada daftar nama kepala ruamh tangga yang akan diberikan dan dilengkapi dengan menulis jenis bantuan, besar dan tanggalnya.

6. Pembagian pada rumah tangga yang belum mendapatkan bantuan akan dicatat pada buku kendali jika ada penyaluran bantuan yang tidak ada alamat dan namanya.

7. Waktu mengantarkan bahan pada ruamh tertentu pengantar harus meminta tandatangan di buku penerimaan (warna hijau)

8. Ada tiga stok pangan jika terjadi masa krisis yaitu di rumah tangga, RW yang dalam bentuk lumbung pangan warga, dan di sistem luar kampung yang meliputi relawan, polisi, TNI, kelurahan.

9. Saat tidak ada stok makanan dan mengalami krisis pangan, masih ada lumbung pangan ini yang akan menjadi penyangga masyarakat untuk melayani masyarakat yang benarbenar tidak memiliki ketersediaan bahan makanan.

10. Lumbung pangan merupangan sarana yang menjadi penghubung di tengah kondisi mencari bahan pangan kepada kelurahan, polres, 
kodim dan tempat yang dibentuk oleh pemerintah sebelumnya.

Dari bentuk bantuan yang tercatat di lumbung pangan kampung akan terkontrol siapa saja yang menyumbang, jumlah, dan siapa saja yang telah mendapatkan bantuan. Pada masa pandemic seperti saat ini bantuan pangan merupakan hal yang positif namun dapat berdampak negatif juga jika pendistribusian bantuan tidak tersusun rapi secara sistematis dan adil maka dapat menimbulkan kecemburuan sosial dan kerusuhan antar warga.

Konsep welfare society merupakan sebuah konsep dari lumbung pangan yang mendorong untuk meningkatkan kesejahteraan masyarakat desa. Konsep ini memberikan perspektif bahwa lumbung pangan desa merupakan pusat pertumbuhan ekonomi dengan dinamika sosial (positif dan progresif).

Alur Penerimaan Bantuan

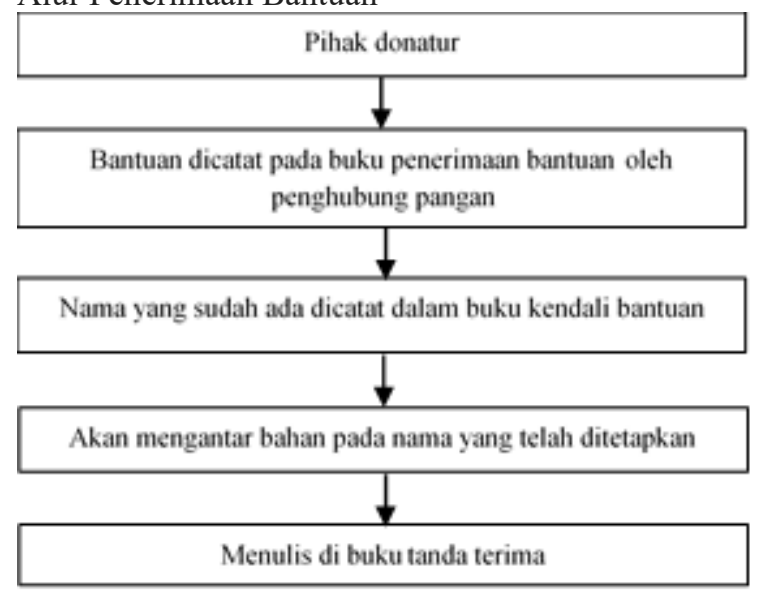

Pendistribusian pangan pada saat covid-19 di desa melalui warga penghubung pangan yaitu RW, kemudian RW bertugas untuk memeriksa ketersediaan stok yang terdapat pada lumbung pangan. Setelah itu akan dilakuka pendataan bahan pangan yang akan dibawa pada buku dengan jumlah maksimal $5 \mathrm{~kg}$ beras per rumah tangga. Penghubung pangan atau RW lalu mengantarkan bahan pangan tersebut untuk diserahkan pada rumah tangga dan juga meminta tanda tangan pada buku kiriman. Kemudian memberikan suatu tanda di buku kendali jika warga terkait telah menerima bantuan [8].

Jenis bahan pangan yang disimpan dalam lumbung pangan diantaranya adalah beras $50 \mathrm{~kg}$, minyak goreng 10 liter, gula $50 \mathrm{~kg}$, mie instan 1 ball, telur $10 \mathrm{~kg}$. Cara yang digunakan warga pengelola lumbung pangan saat kondisi masyarakat belum kekurangan pangan, supaya bahan pangan tersebut tidak basi, adalah dengan menitipkan ke warga yang memiliki toko, supaya bahan pangan tersebut bisa diperjualbelikan dengan harapan bahan persediaan pangan tersebut tidak kadaluwarsa selama belum digunakan untuk kebutuhan warga. Adapun bahan pangan yang dititipkan ke warung warga berupa: beras $40 \mathrm{~kg}$, minyak goreng 10 liter, gula $50 \mathrm{~kg}$, mie instan 1 ball, telur $10 \mathrm{~kg}$. Di lumbung hanya menyisakan beras $10 \mathrm{~kg}$. Petinipan di toko warga dilakukan dengan seijin ketua dan pembina tim penanganan Covid-19 Desa Kabuaran dan disertai dengan berita acara serah terima.

Selain bahan pangan tersebut, karena desa kabuaran mempunyai kebun toga dan mempunyai prestasi sebagai juara 1 lomba tanaman toga tingkat kecamatan dengan inovasi minuman sehat penjaga daya tahan tubuh yaitu minuman Jahe Serai Gula (JSG). Maka warga juga menyediakan minuman olahan tersebut. Dimana banyak sekali manfaat kandunan dalam jahe dan serai dalam minuman olahan tersebut.

Jahe (Zingiber Officinale) adalah suatu jenis rempah yang efektif dapat melawan flu dan demam. Selain itu, Khasiatnya dapat menghangatkan bagian tubuh dan saluran pernafasan, meredakan batuk, mengencerkan dahak, merangsang imunitas tubuh, dan antiradang [6]. Jahe mengandung beberapa zat yaitu vitamin A, B, C, lemak, protein, pati, dammar, asam organic, oleoresin (gingerin), dan minyak terbang (zingeron, zingerol, zingeberol, zingberin, borneol, sineol, dan feladren). terdapat beberapa kandungan lain juga pada jahe yaitu minyak atsiri dan oleoresin. Kandungan minyak atsiri paling tinggi terdapat pada jahe merah, kemudian jahe putih dan terakhir jahe gajah. Jahe gajah ini paling terkenal karena digunakan sebagai bahan bumbu dapur [14]. Manfaat jahe ini memiliki kendungan zat kimia yang begitu banyak, tidak hanya enak namun juga dibuat sebagai minuman dan dicampur sebagai bahan masakan, tetapi juga berguna untuk daya tahan tubuh. Jahe ini dapat meningkatkan sistem kekebalan tubuh. Dari meningkatnya imun, sehingga dapat mencegah bakteri dan penyakit masuk sehingga kebugaran dan stamina tubuh akan meningkat. Mengkonsumsi jahe juga dapat membuat tubuh terasa hangat dan jadi berkeringat. Dari keringat yang keluar tersebut kotoran dan bakteri dapat dikeluarkan oleh tubuh. mengkonsumsi jahe juga dapat membantu mengatasi dehidrasi [5].

Serai (Cymbopogan citratus) dikenal juga dengan nama sereh merupakan tanaman yang termasuk jenis rumput-rumputan. Batang serai banyak digunakan sebagai rempah bmbu masakan, terutama bahan dasar daging. Aroma serai yang 
khas dan harum menjadikan tanaman ini sebagai inuman yang menyegarkan [15].

Manfaat serai didapatkan dari kandungan antioksidan dan anti radang. Manfaat daun serai ini dapat mengatasi dan mencegah berbagai masalah kesehatan yang didapatkan dengan cara meminum air rebusan batang dan daun serai. Manfaat daun serai secara khusus dalam imunitas yaitu :

1. Serai sebagai antioksidan

Serai mengandung beberapa antioksidan yang dapat membantu mengurangi radikal bebas dalam tubuh yang dapat menyebabkan penyakit. Antioksidan serai yaitu asam klorogenik, isoorientin dan swetiajaponin.

2. Serai sebagai antimikroba

Serai yang direbus digunakan untuk infeksi muut dan gigi berlubang. Bakteri streptococcus mutans merupakan bakteri yang dapat merusak gigi, bakteri ini dapat dilawan oleh antimikroba pada minyak serai.

3. Serai sebagai anti peradangan

Sebagai anti peradangan, serai memiliki dua senyaawa utama yaitu citral dan geranial. Dua zat ini sebagai anti peradangan sehingga dapat mencegah flu, sakit tenggorokan dan juga berbagai masalah pencernaan akibat peradangan.

4. Risiko kanker dapat dikurangi

Sebagai anti kanker, citral memiliki kemampuan dalam menghamabat beberpa sel kanker.

5. Serai sebagai detoksifikasi tubuh

Dalam melancarkan buang air kecil serai sebagai diuretik alami. Kelebihan cairan natrium dapat dibersihkan dengan buang air kecil sehingga merangsang ginjal untuk mengeluarkan lebih banyak utin. Efek diuretik ini membantu membersihkan ginjal dan meningkatkan fungsinya.

6. Untuk mengurangi kecemasan

Kecemasan yang berlebih dapat dikurangi dengan teh serai, karena dapat membantu dalam rileksasi alami tubuh. Teh memiliki aroma yang dapat mengurangi tingkat kecemasan dan memberikan ketenangan sehingga efek ini dapat membantu tidur dengan nyenyak. Insomnia akibat kecemasan juga dapat dikurangi dengan aroma teh serai ini [7]. Untuk penyimpanannya pengelola lumbung pangan juga menitipkan minuman tersebut ke warga yang memiliki toko dengan pendingin minuman.

\section{Kesimpulan}

Panitia kampung tangguh membuat Lumbung Pangan Komunitas atau LPK untuk membentuk suatu ketangguhan pangan sehingga masyarakat tidak selalu bergantung kepada pemerintah dan memberikan manfaat dengan memberikan sumbangan sebagai bentuk upaya gotong royong dalam masyarakat yaitu warga terdampak mendapatkan bantuan dari warga yang mampu. Bantuan pangan ini terutama bagi warga yang tidak mampu untuk menghindari masalah sosial dan meminimalisir penyebaran penyakit selama mengikuti aturan pemerintah.

Rekomendasi warga mampu untuk membentuk lumbung pangan untuk setiap RT dengan mengisi formulir yang berisikan jenis bantuan, jumlah serta tanda tangan penyumbang. Lumbung pangan ini menjadikan kampung yang tangguh sehingga dapat berdaya di tengah pandemi covid-19 untuk mencapai kampung tangguh yang mampu mandiri.

\section{Ucapan Terimakasih}

Penyusunan artikel ini dibimbing dan dibantu oleh berbagai pihak. Terima kasih penulis ucapkan kepada Prof. Dr. Ir. Rudi Wibowo, MS. beliau selaku Direktur Pascasarjana Universitas Jember; Dr. Isa Ma'rufi, S.KM., M. Kes. beliau selaku Ketua Program Studi Magister Ilmu Kesehatan Masyarakat Universitas Jember sekaligus menjadi dosen pembimbing yang memberikan banyak arahan sehingga artikel ini dapat tersusun dengan baik; Bapak Bambang Irawan selaku Kepala Desa Kabuaran, Kecamatan Grujugan, Kabupaten Bondowoso sekaligus menjadi narasumber dalam wawancara kegiatan residensi juga memberikan izin untuk melakukan upaya promotif dan preventif covid-19; serta Teman-teman Pascasarjana Ilmu Kesehatan Masyarakat yang turut membantu; serta semua pihak yang tidak dapat disebutkan satu per satu.

\section{Referensi}

1. Aria, Pingit. 2020. Masalah Pangan Menjelang Ramadan di Tengah Pandemi Covid-19.

2. BPS. 2020. Laporan Bulanan Data Sosial Ekonomi Mei 2020.

3. Food and Agriculture Organization of The United Nations [FAO]. 2020. Addressing the Impacts of COVID-19 in Food Crises, April - December 2020. FAO's Component of The Global COVID-19 Humanitarian Response Plan.

4. Hirawan, Fajar. B dan Verselita, Akita A. 2020. Kebijakan Pangan di Masa Pandemi COVID-19. CSIS Commentaries DMRU-048-ID, 18 Desember 2020.

5. Jauhary, Hamidah. 2020. Sehat Tanpa Obat Khasiat Tersembunyi Jahe. Yogyakarta : Andi Offset.

6. Jusup, Lenny. 2002. 50 Resep Makanan Untuk Menigkatkan Daya Tahan Tubuh. Jakarta : PT. Gramedia Pustaka Utama.

7. KBM Indonesia. 2020. Ensiklopedia Serai (Deskripsi, Filosofi, Manfaat, Budidaya, dan Peluang Bisnis. Yogyakarta : Karya Bakti Makmur.

8. Nagara, A. Y., Prawestiningtyas, E., Putri, A. D. J. J., Putri, F. R., Nurwanti, R., Purnomo, M., Santoso, B., Yuda, A., Permadi, H., Galang, H., Prasetyo, R. E., Pranowo, D., Anwar, K., Nugroho, T. W., Zamroni, M., Hadi, M. S., Yusuf, N., Ainun, Y., Sudarmaji, ... 
Sunarto, B. P. (2020). Pedoman Pengoprasian Kampung Tangguh. In Journal of Chemical Information and Modeling (3.0). SATGAS COVID 19 UB Gedung Rektorat Lantai 1 Universitas Brawijaya.

9. Peraturan Pemerintah Nomor 83 Tahun 2017 tentang Ketahanan Pangan dan Gizi

10. Puguh, D., Rivera, M., \& Fazri, M. (2020). " Covid 19: Menakar Ketahanan Pangan Di Desa ."

11. Rachmat, M., Budhi, G. S., Supriyati, N., \& Sejati, W. K. (2016). Lumbung Pangan Masyarakat: Keberadaan dan Perannya dalam Penanggulangan Kerawanan Pangan. Forum Penrelitian Agro Ekonomi, 29(1), 43.

12. Ridhoi, M. Ahsan. 2020. Pasokan Pangan Dunia Terguncang Covid-19, Bagaimana di Indonesia?

13. Rohman, T. (2019). Malay Local Wisdom in the Period and After the Plague. In Psikologi Perkembangan (Issue October 2013)

14. Setyaningrum, Hesti Dwi dan Suprianto, Cahya. 2013. Jahe. Jakarta : Penebar Swadaya.

15. Savitri, Astrid. 2016. Tanaman Ajaib Basmi Penyakit dengan Toga (Tanaman Obat Keluarga). Jakarta : Bibit Publisher.

16. Undang-Undang Nomor 41 Tahun 2009 tentang Perlindungan Lahan Pertanian Pangan Berkelanjutan. 